\title{
Survival and long-term maintenance of tertiary trees in the Iberian Peninsula during the Pleistocene: first record of Aesculus L. (Hippocastanaceae) in Spain
}

\author{
José María Postigo Mijarra \\ Fernando Gómez Manzaneque \\ Carlos Morla
}

\begin{abstract}
The Italian and Balkan peninsulas have been places traditionally highlighted as Pleistocene glacial refuges. The Iberian Peninsula, however, has been a focus of controversy between geobotanists and palaeobotanists as a result of its exclusion from this category on different occasions. In the current paper, we synthesise geological, molecular, palaeobotanical and geobotanical data that show the importance of the Iberian Peninsula in the Western Mediterranean as a refugium area. The presence of Aesculus aff. hippocastanum L. at the Iberian site at $\mathrm{Cal}$ Guardiola (Tarrasa, Barcelona, NE Spain) in the LowerMiddle Pleistocene transition helps to consolidate the remarkable role of the Iberian Peninsula in the survival of tertiary species during the Pleistocene. The palaeodistribution of the genus in Europe highlights a model of area abandonment for a widely-distributed species in the Miocene and Pliocene, leading to a diminished and fragmentary presence in the Pleistocene and Holocene on the southern Mediterranean peninsulas. Aesculus fossils are not uncommon within the series of Tertiary taxa. Many appear in the Pliocene and suffer a radical impoverishment in the Lower-Middle Pleistocene transition. Nonetheless some of these tertiary taxa persisted throughout the Pleistocene and Holocene up to the present in the Iberian Peninsula. Locating these refuge areas on the Peninsula is not an easy task, although areas characterised by a sustained level of humidity must have played an predominant role.
\end{abstract}

Keywords Aesculus - Pleistocene - Iberian Peninsula . Fossil wood . Quaternary refugia

\section{Introduction}

The Pleistocene vegetation of the Iberian Peninsula is currently poorly known for reasons such as lack and fragmentary nature of data and the inaccuracy of some dating. Recent data increasingly indicate the presence of Tertiary species during the glacial periods inland on the Peninsula, thus supporting the idea that this constituted an important area for the survival of tertiary taxa during the Quaternary.

Study of the palaeodistribution of the genus Aesculus helps us to clarify the role of the Iberian Peninsula and of the other Mediterranean peninsulas in the Quaternary, and is therefore of great interest to biogeographers. Hardin (1957a) proposed Central America as the origin of the diversification of the genus and subsequent migration to Asia, while Raven and Axelrod $(1974,1978)$ suggested that it originated in North America. However, the latest studies appear to indicate that the genus originated at high latitudes in eastern Asia during the transition from the Cretaceous to the Cenozoic, forming part of the boreotropical element around $65 \mathrm{Ma}$ and subsequently spread to become part of the boreotropical element in North America and Europe (Xiang et al. 1998).

The present populations of this genus can be interpreted as relict fragments of widely-distributed populations in the Miocene and Pliocene, although there is little fossil evidence to corroborate this (Hardin 1960). The genus currently comprises 13 species (Fig. 1). In North America, the Parryanae Wiggins section is represented by one 
species, A. parryi Gray and the Calothyrsus (Spach) $\mathrm{K}$. Koch section is represented by A. californica (Spach) Nuttall. The Macrothyrsus (Spach) K. Koch section is represented by $A$. parviflora Walter, this being the only representative in Alabama and Georgia. The Pavia (Mill) Persoon section is represented in the East and Southeast of the United States by five taxa: A. glabra var. glabra, A. glabra var. arguta (Buckl.) Robinson, A. octandra Marshall, A. sylvatica Bartram and A. pavia L. In eastern Asia, the Calothyrsus (Spach) K. Koch section comprises A. californica (Spach) Nuttall, A. chinensis Bunge, A. wilsonii Rehder, A. indica (Camb.) Hook and A. assamica Griffith. (Hardin 1957b, 1960). Lastly, the Aesculus section combines $A$. turbinata Blume, a Japanese endemic, and A. hippocastanum L., found in Europe.

In Europe the genus Aesculus is represented in the fossil record dating back to at least the Lower Miocene. There is reference to it in France, as forming part of the so-called Flora Aquitaniense as Caragana aquensis (Gregor 1990) and in the North of Greece (Kimi) as Aesculus "jovis" or Aesculus "polydris" (Velitzelos and Gregor 1990). It has also been referred to in the Miocene in Sicily (Mariotti Lippi 1989), Germany and Holland (Szafer 1961; Mai 1965; Zagwijn 1967) and in Eastern Europe, (Chiuzbaia: Givulescu 1990). As will subsequently be pointed out, however, its greatest spread was during the Pliocene. At present the horse chestnut, A. hippocastanum L., is endemic to the mountains of the Balkan Peninsula, specifically Bulgaria, northern Greece and southern Albania, where it is found at altitudes of between 700 and $1,830 \mathrm{~m}$ (Hardin 1960). It is a mesophytic taxon associated with humid valleys, ravines and river-heads on stony, well-drained soil, both acidic and alkaline, where it cohabits with Fagus, Juglans, Alnus, Acer, Fraxinus, Tilia, Corylus and Cornus (Polunin and Walters 1989).

The survival of the genus in Europe is closely linked to the active role of the Mediterranean peninsulas in the Quaternary. In our paper, the macroremains found highlight the possible role played by the Iberian Peninsula during the Pleistocene, during which the peninsula provided a suitable place for the maintenance of populations of great phytogeographic interest throughout the Quaternary.

\section{The study area: the Cal Guardiola site}

The Cal Guardiola site is located in the municipality of Tarrasa (Barcelona, Spain) (UTM: 31TDG1702; geographical co-ordinates: $42^{\circ} 26^{\prime} 05^{\prime \prime} \mathrm{N} 2^{\circ} 00^{\prime} 6^{\prime \prime} \mathrm{E}$ ) in the $\mathrm{NE}$ of the Iberian Peninsula (Fig. 2). It is situated in the tectonic trough of the Vallés-Penedés region, which forms part of the NE-SW aligned Costero-Catalana Mountains, which stretch for around $250 \mathrm{~km}$. The relief of the area is largely defined by the system of faults generated during the preorogenic (Mesozoic) and compressive (Paleogene) phases, establishing the main features of the relief and demarcating the depressions that were subsequently in-filled during the Neogene with different materials (Fig. 3). Lithologically they constitute sedimentary materials of continental facies, mainly argillites, sandstones and puddingstones, in sedimentary conditions similar to those of the Vindobonian upon which they lie. Along the Vallés depression, deposits of quaternary materials can be found. These may be associated with river terraces like those of the rivers Llobregat, Besós, Segre and Cardoner (Gutiérrez Elorza 1994).

From the stratigraphic perspective, the Cal Guardiola site comprises a $5.5 \mathrm{~m}$ thick sequence containing a set of strata formed by three cycles of sedimentation (mostly gravels with little granulometric selection). The origin of these is the result of successive alluvial fans alternating with sedimentary units that accumulated by means of water circulation of varying intensity (Berástegui et al. 2000). A set of sediment bodies can be differentiated in the lower Cycle I. The first of these is superimposed on the Upper Miocene (Tortonian) series and appears to have been shaped by hydric flows of varying intensity. A subsequent phase involves a lower-energy environment that gave rise to the main sedimentary unit referred to as Level D2. The

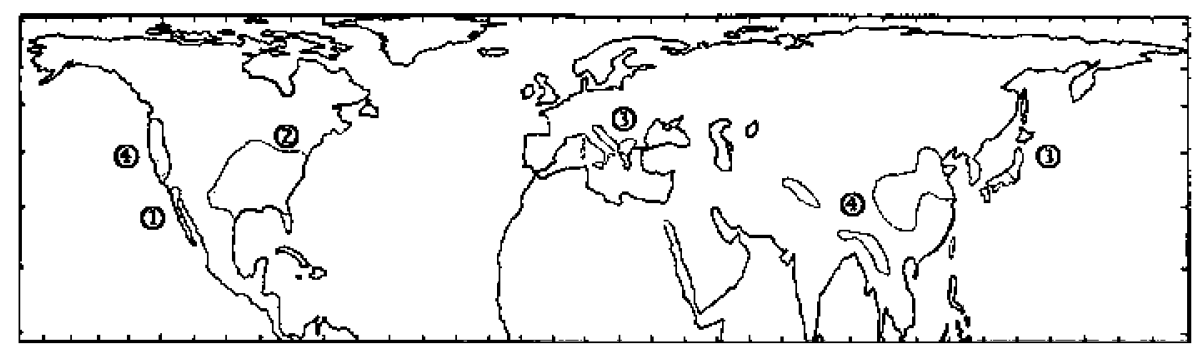

Fig. 1 Current distribution of the genus Aesculus, modified from Carrol and Wood (1972), based on Hardin (1957a, 1960). I Section Parryanae (Aesculus parryl); 2 Section Pavia (A. pavia, A. glabra, A. octandra and A. sylvatica) and Section Macrothyrsus (A. parviflora);
3 Section Aesculus (A. hippocastanum and A. turbinata); 4 Section Calothyrsus (A. californica, A. indica, A. assamica, A. wilsonii and A. chinensis) 


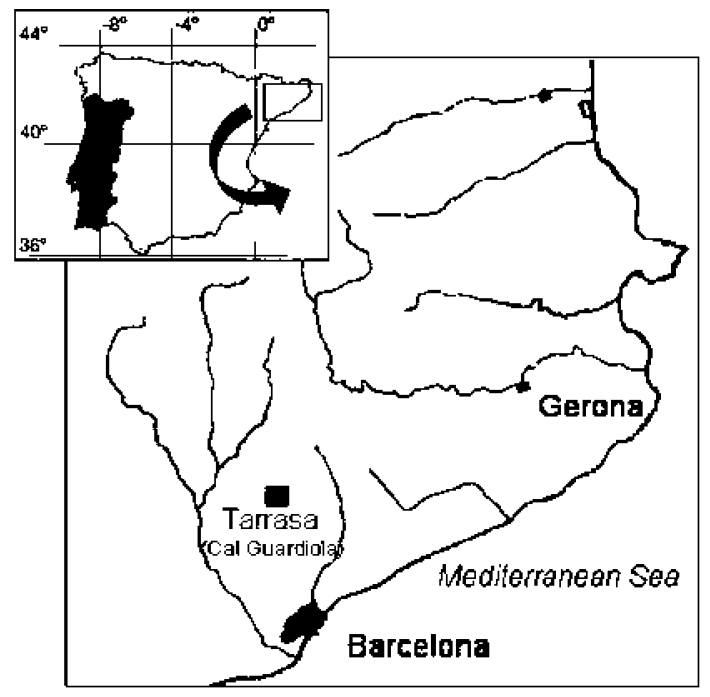

Fig. 2 Location of the Cal Guardiola site in Catalonia (Iberian Peninsula)
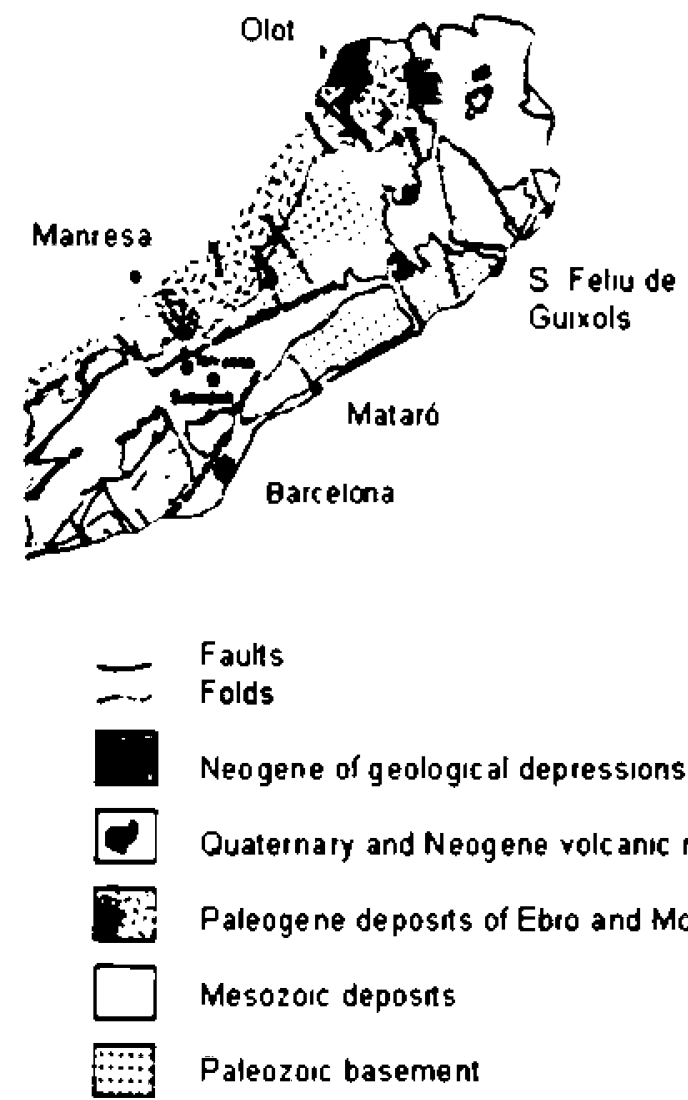

Fig. 3 Tectonics of the eastern zone of the Costero-Catalana Mountains (modified from Sala, 1994)

subsequent sedimentary units indicate the continuation of the sedimentation, although the hydric flow appears to be less intense, with a decrease in the gravel fraction (Fig. 4).
An archeaopalaeontological excavation was undertaken over an area of some $691 \mathrm{~m}^{2}$. The sampling of wood was undertaken at the excavation site by a team from the Miquel Crusafont Palaeontological Institute and the Universitat Autònoma de Barcelona during 1997. All fossils were collected from in situ resting sites.

\section{Materials and methods}

The wood samples collected were all found in Level D2 mentioned above. They were stained black by the accumulated sediments and preserved under anoxic conditions. Level D2 contained a very diverse series of animal remains, some with partial anatomical connection, and abundant plant remains amongst which the non-carbonised wood was found. The wood shows signs of biodegradation, carbonification, taphonomic distortion and, in some cases, pyritization. However, the tissues are well preserved and the absence of mineralisation allows the wood to be classified as duripartically preserved (Schopf 1975) or preserved in a basically unaltered state (Spicer 1991). The subsequent sediment units indicate the continuation of the sedimentation, although with a less intense flow of water, a decrease in the gravel fraction and no plant organic remains.

We selected twelve wood fossils from the set and analysed them using traditional methods of microscopic study of wood (Schweingruber 1978; de Palacios 1997). Using this technique we obtained wood fragments, measuring approximately $1 \times 1 \times 2 \mathrm{~cm}$ which we cut in the microtome. The thin slices, approximately $15-20 \mu \mathrm{m}$ thick, were placed on a watch glass, first in distilled water, and then were stained with safranine and washed with distilled water and alcohol. After repeated washing, the samples were submerged in xylol. A few drops of a fixer, Euquit, were then added. We then examined the slices by transmitted light microscopy using an Olympus Bx50 series optical microscope with UIS lenses at magnifications of $50 \times$, $100 \times, 200 \times$ and $500 \times$.

In order to identify the samples, we used classical wood anatomy studies: Greguss (1947), Jacquiot et al. (1973), García and Guindeo (1990) and Schweingruber (1990). To date the samples we used the palaeomagnetic analyses conducted at the Jaume Almera Institute (C.S.I.C), the magnetostratigraphic analysis of which clearly placed the stratum below the Brunhes-Matuyama geomagnetic boundary, that is at an age of less than $0.78 \mathrm{Ma}$ (J.M. Garcés, personal communication). We also incorporated the correlation with micro-mammals such as Mimomys savini Hinton or Allophaiomys burgondiae Chaline. Thus, considering all these data, the age of Cal Guardiola could be established within an interval of between 1.2 and $0.8 \mathrm{Ma}$. 
Fig. 4 Stratigraphical sequence at Cal Guardiola site (Berástegui et al. 2000)

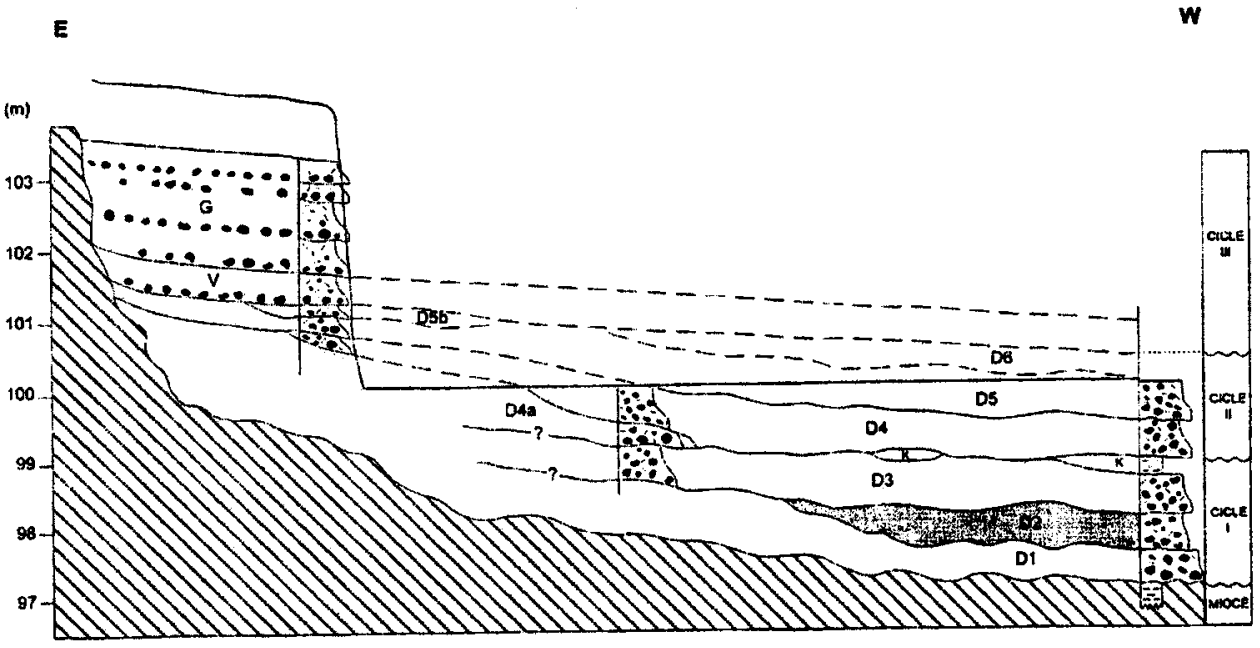

The presence of some thermophylous taxa, such as mammals and plant remains at Cal Guardiola, suggests a warm-temperate episode (Berástegui et al. 2000; Burjachs 2000; Postigo 2003).

\section{Results and discussion}

First evidence of Aesculus aff. hippocastanum in the Iberian Peninsula

The microscopic study from the site provides initial results identifying 12 fragments of fossil wood with the following anatomical features (Table 1):

Table 1 Most relevant anatomical characteristics of samples of Aesculus aff. hippocastanum present at the site

\begin{tabular}{lllll}
\hline Sample & DPP & DPV & AV & LR \\
\hline 1 & $40-50$ & $25-40$ & $2-3(4)$ & $8-15 / 150-300$ \\
2 & $25-30$ & $20-30$ & $2-4$ & $10-12 / 150-200$ \\
3 & $25-30$ & $20-25$ & $2-3$ & $2-13(18) / 200-250$ \\
4 & $30-35$ & $20-30$ & $2-4$ & $8-12 / 100-200$ \\
5 & $35-40$ & $20-25$ & $2-3(4)$ & $7-15 / 200-300$ \\
6 & $20-40$ & $20-30$ & $2-3(4)$ & $6-12 / 60-150$ \\
7 & $30-40$ & $25-30$ & $2-4(5)$ & $5-10 / 100-175(250)$ \\
8 & $30-40$ & $20-30$ & $2-4$ & $9-13 / 140-190$ \\
9 & $25-30$ & $20-30$ & $2-3(4)$ & $14-16 / 220-240$ \\
10 & $40-50$ & $20-35$ & $2(3)$ & $6-11 / 180-230$ \\
11 & $20-40$ & $10-40$ & $2-4$ & $9-12 / 130-240$ \\
12 & $30-40$ & $30-40$ & $2-4$ & $8-12 / 90-180$ \\
\hline
\end{tabular}

$D P P$ mean diameters of the early wood vessels; $D P V$ mean diameters of the latewood vessels; $A V$ grouping of vessels (number of elements); $L R$ : length of the rays (number cells/length in microns). All measurements are expressed in microns
- Transversal section diffused or semi-diffused pores. Growth ring boundaries marked. The pores are solitary or appear in radial rows of between 2 and 5 elements (Fig. 5). The average diameter of the pores in the early wood is $30-40 \mu \mathrm{m}$, and that of the late wood pores 20 $25 \mu \mathrm{m}$. We were unable to identify any type of parenchyma distributed along this plane. The pits are simple ones, with a hexagonal areola. Gums and other deposits in heartwood vessels present.

- Radial section: the rays are homogeneous, and simple perforations can be seen (Figs. 5, 2). Spiral thickenings can be found in vessels, although these are thin (Figs. 5, 3). Libriform fibres present.

- Tangential section: strictly uniseriate rays, mainly homogeneous, average height 5-18 cells (Figs. 5, 4). Average length of uniseriate rays $200-300 \mu \mathrm{m}$.

The characters observed lead us to assign our samples to the family Hippocastanaceae, genus Aesculus (Greguss 1947; Jacquiot et al. 1973; García and Guindeo 1990; Schweingruber 1990). There are no available comparative anatomical wood studies of the representatives of this genus, which is why we cannot make an accurate discrimination based upon anatomical study of their species. However, the distribution and specific representation of Aesculus in the Miocene, Pliocene and the Pleistocene does enable us to assign them to $A$. aff. hippocastanum, at present confined to its natural distribution area in the Balkans. The presence of another species belonging to the genus at this point in the Pleistocene on the Iberian Peninsula is unlikely in view of the current distribution of the species.

The reference to Aesculus aff. hippocastanum at the $\mathrm{Cal}$ Guardiola site is the first for the Iberian Peninsula and constitutes one of the most recent ones for the genus prior to its current radical reduction of distribution area to the Balkans. We only have one possible reference to the 
Fig. 5 Wood from Aesculus aff. hippocastanum; 1 Sample number 1235 , transversal section. Aesculus aff. hippocastanum. Rings marked with diffuse porous isolated elements or in small radial groups. Scale-bar $100 \mu \mathrm{m}$; 2 Sample number 1235, radial section. Aesculus aff. hippocastanum. a simple perforation plate. $\mathbf{b}$ Vessel with inter-vessel pits in which the fine spiral thickenings can be observed. Scale-bar $=20 \mu \mathrm{m}$; 3 Sample number 950, radial section. Aesculus aff. hippocastanum. Detail of vessel with spiral thickenings. Scalebar $=10 \mu \mathrm{m} ; 4$ Sample number 1235 , tangential section.

Aesculus aff. hippocastanum. Uniseriate homogeneous rays. Scale-bar $=75 \mu \mathrm{m}$
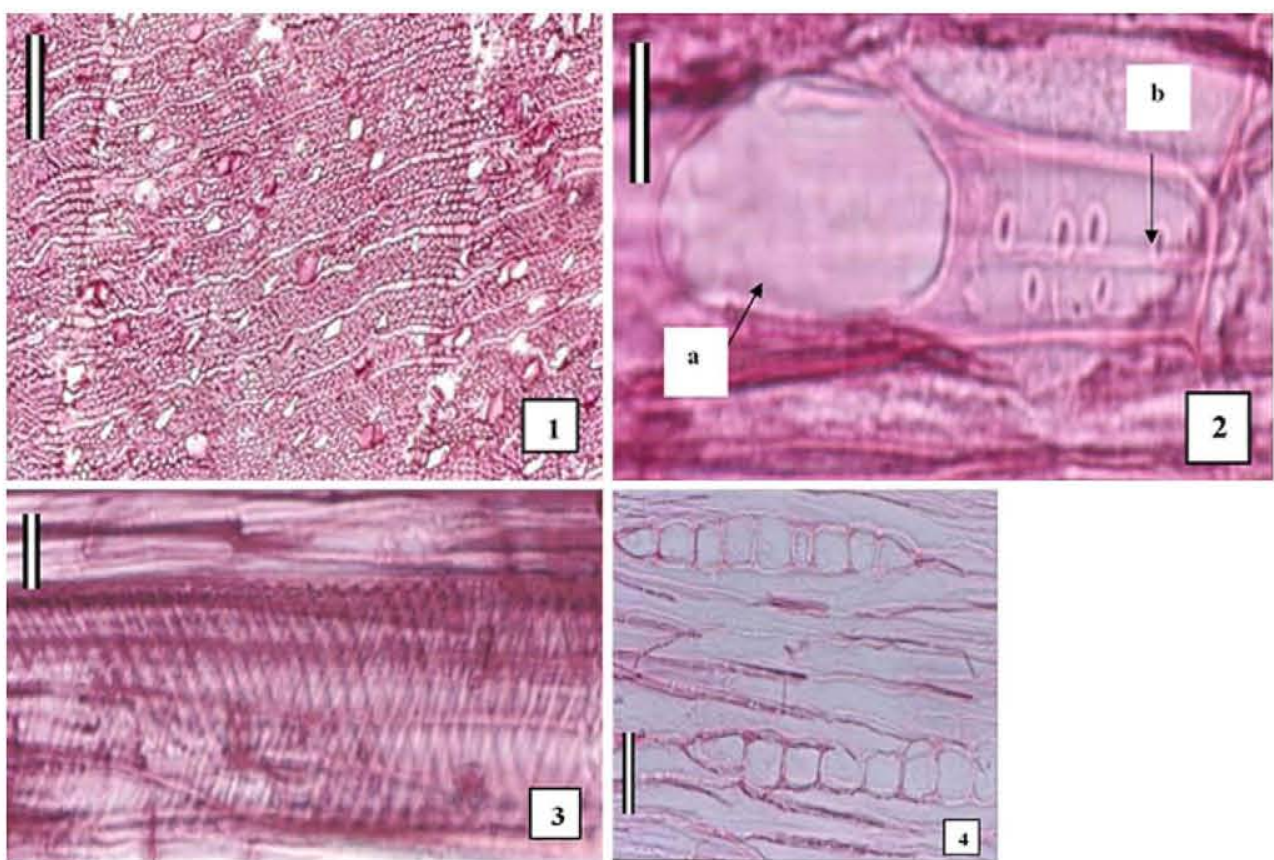

Peninsula throughout the whole Cenozoic (Valle and Civis 1978), which indicates as "dubious" the pollen from an angiosperm which might correspond to the family Hippocastanaceae and within this might be referred to Aesculus. In a subsequent synthesis study (Valle 1983), no mention is made of this occurrence. The Cal Guardiola reference therefore confirms the presence of the genus in the fossil record for the Peninsula and constitutes the first reference in Europe based on the microscopic characteristics of the wood.

The palaeobiogeography of Aesculus in Europe.

A regression model

If we analyse the palaeodistribution of the genus Aesculus in Europe we see that it occupied a vast area in central and northern Europe and in the Mediterranean area during the Miocene and Pliocene. The greatest spread of the genus occurred during the Pliocene (Fig. 6), a period during which it was widely distributed, data existing on its presence throughout the Mediterranean, including North Africa and central and northern Europe. The lack of intense summer drought, along with the absence of extreme temperature differences, allowed for this expansion. At the end of the Pliocene, probably as a result of climate changes, the genus suffered a drastic population reduction, a phenomenon that equally affected many taxa (van der Hammen et al. 1971; Svenning 2003).

There are a very few references to the taxon in the Pleistocene, all of these being from southern Europe and the Mediterranean area. In France, dated to the Lower Pleistocene (1.37-1.2 Ma), pollen belonging to A. hippocastanum, and referred to as rare, has been identified in Grotte du Vallonnet (Renault-Miskovsky and Girard 1978). This was from an environment showing abundant plant cover, with well-represented European xerophytic taxa together with a wide range of thermophylous broad-leaved species typical of more humid environments, including among others Quercus pubescens-type, Ulmus, Pterocarya, Platanus, Juglans and Carpinus.

The taxon has most often been referred to from the Italian peninsula, always through the pollen record. In northern Italy it appears in Lombardy (Sordelli 1896; Ravazzi and Rossignol 1995), associated with a temperate warm phase exhibiting a wide range of thermohygrophylous and hygrophylous species such as Carya, Pterocarya, Juglans, Eucommia, Parthenocissus and Fagus. At the Plio-Pleistocene site of Stirone River (Bertolani et al. 1979) Aesculus appears associated with phases presenting an abundance of species such as Carya, Carpinus or Eucommia. At Piedrafitta (Lona and Bertoldi 1972) a biozone occurred dominated by mesocratic taxa with Fagus, Castanea, Pterocarya, Carya and Pinus haploxylon. Lastly, and also in Italy, Aesculus appears at the Fornace Tini site (Urban et al. 1983) approximately 1.9-1.8 Ma ago. Here the pollen remains indicate the existence of a wide range of thermophylous species among which we can highlight Carya, Castanea, Pterocarya, Nyssa, Fagus, Eucommia, Liquidambar and Liriodendron. In the upper part of the diagram, in zone FT VII, Aesculus can be found, accompanied by the above-mentioned ensemble of thermophyles. 


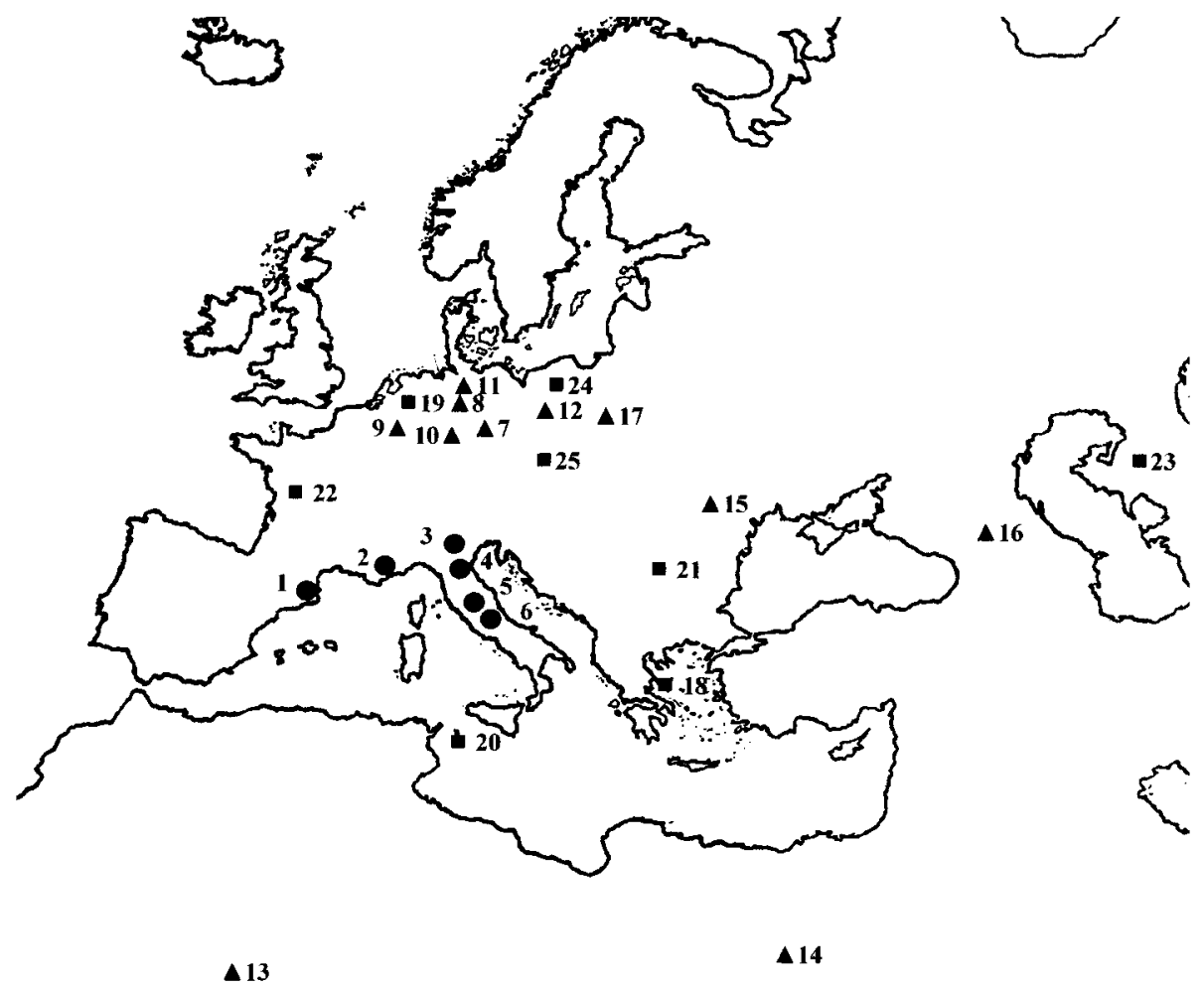

Fig. 6 Palaeodistribution of Aesculus. Pleistocene (filled circle): 1 Cal Guardiola (Postigo Mijarra 2003); 2 Grotte du Vallonnet (Renault-Miskovski and Girard 1978); 3 Lombardía (Sordelli 1896; Ravazzi and Rossignol 1995); 4 Stirone river (Bertolani et al. 1979); 5 Piedrafitta (Zittel 1891; Lona and Bertoldi 1972). 6 Fornace Tini (Urban et al. 1983). Pliocene (filled triangle): 7 Willerhausen (Ferguson and Knobloch 1998); 8 Fortuna Garsdorf (van der Burgh 1978); 9 Hammbach (van der Burgh and Zetter 1998); 10 Francfort (Zittel 1891; Mädler 1939); 11 Frontera Dutch-Prussian (Reid and

Within the Mediterranean flora, this group of genera, including Aesculus, appears to be a part of what is known as the Holarctic or Eurasian element, and more specifically belongs to a mesothermic sub-element of pre-Miocene origin (Quézel 1985).

We can therefore conclude that in Europe Aesculus belonged to deciduous communities typical of temperatewarm climate or phases, which were relatively abundant during the Pliocene and it appeared in humid environments such as valley bottoms, river-heads, mid-mountain hygrophylous forests or forests on temporarily flooded soils. Pleistocene climate changes notably reduced the distribution area of these communities, and they found some places for survival in southern Europe and the Mediterranean peninsulas. The palaeodistribution of Aesculus in Europe might indicate a retreat model for taxa of wide pre-Quaternary distribution to limited Quaternary populations in the South, finally contracting to relict populations in the Holocene. Within this pattern of disappearance, the active role played by the Mediterranean peninsulas should be highlighted and among these we should include the Iberian

Reid 1915); 12 Wieliczka (Zittel 1891). 13 Hoggar (Maley 1980); 14 Kourkour (Maley 1980); 15 Precarpacia (Ilinskaja 1968); 16 Precaúcaso (Chochieva 1965); 17 Czorsztyn (Szafer 1954). Miocene (filled square): $18 \mathrm{Kimi}$ (Velitzelos and Gregor 1990); 19 Born (Zagwijn 1967); 20 Eraclea Minoa (Mariotti Lippi 1989); 21 Chiuzbaia (Givulescu 1990); 22 Flora Aquitaniense (Gregor 1990); 23 Ustjurt Plateau (Zhilin 1974); 24 Belchatow (Worobiec 2003); 25 Kundratitz (Engelhardt 1885)

Peninsula. This area abandonment model might have been followed by other species which are now relegated to southern Europe, like the horse chestnut in the Balkans, or to parts of SE Europe. It might also have been the case for Platanus, Liquidambar or Syringa. The presence of the horse chestnut in the Lower-Middle Pleistocene transition on the Iberian Peninsula clearly shows that this region acted as a suitable place for the maintenance of this type of species through the Pleistocene.

The controversial role of the Iberian Peninsula as a refuge area

The orographic peculiarities of Central South and Northwest Europe, and the climate differences between the regions, call for studies based on the evolution of the Mediterranean peninsulas and of the southern part of the continent. These areas might have suffered particular quaternary dynamics with some significant differences (Bertoldi et al. 1989). The survival of temperate taxa such 
as Aesculus during the Pleistocene in southern Europe involves a history that is closely linked to the function of the Mediterranean peninsulas throughout this period. In this context, the role played by the Iberian Peninsula has been a subject of great controversy over the last few decades. Thus, for some authors, the Italian and Balkan peninsulas have been almost the only places traditionally considered to constitute a refuge area (van der Hammen et al. 1971; Huntley and Birks 1983). Furthermore, other authors have clearly rejected the role of the Iberian Peninsula as a potential refuge, arguing that "it does not appear to have been a refuge area, as the region was probably too arid and its mountain ranges too small for viable tree populations" (Bennett et al. 1991). Moreover, cpDNA-based studies related to glacial refuges in the Pleistocene indicate a low level of diversity for Iberian forests compared with those of other peninsulas. This might be related to the fact that the Pyrenees did not constitute a solid barrier against colonisation following the last glaciation and that the Iberian Peninsula may have been particularly exposed to the different climatic episodes during the Quaternary (Petit et al. 2003). These authors suggest that surviving thermophylous populations were small and were situated further south than in other parts of Europe.

However fossil evidence, including the new Aesculus fossil presented in the current paper, as well as studies using molecular markers, supports the thesis that, as with the other peninsulas, the Iberian Peninsula must have played an important role in the survival and long-term maintenance of Tertiary trees during the Quaternary. Simultaneously, the Iberian Peninsula would have been a re-colonisation source area following the retreat of the ice in the Upper Pleistocene (Costa Tenorio et al. 1997; Hewit 1999).

The tertiary taxa in the Pleistocene fossil record

The fate of European Pliocene genera was determined to a great extent by their climatic requirements (Svenning 2003). In northern Europe the early pattern of extinction of tertiary taxa is well known. According to Zagwijn (1960), significant taxa such as Aesculus, Engelhardia, Liquidambar, Nyssa, Symplocos or Zelkova disappeared during the Plio-Pleistocene transition.

In southern Europe, these taxa were well represented up to much more recent periods (Lower-Middle Pleistocene), their presence at sites in southern Europe being relatively common during this part of the Pleistocene. There is a good record of them in Italy at Fornace Tini (Urban et al. 1983), Leffe Basin (Ravazzi and Rossignol 1995), Rio Ferraio, Piedrafitta and Stirone (Lona and Bertoldi 1972). Similar results are obtained at other sites in France, such as the sites at Bernasso, Saint-Martial and Durfort (Suc 1976). At Bresse, (Jan du Chene 1976), these types of taxa were recorded throughout much of the Lower Pleistocene, disappearing during the mid-Tiglian, while other tertiary taxa such as Eucommia or Castanea survived up to the Upper Tiglian. The well-diversified Juglandaceae and Taxodiaceae flora of the Upper Pliocene initially outlived the preTiglian, although they did not survive the Upper Tiglian. Very similar results in relation to the evolution of these floras were recorded in France, in the Massif Central at the Mont-Doré site (Brun 1976). At Tenaghi Philippon a significant group of tertiary taxa has been also recorded through the Middle and Upper Pleistocene although the extreme glacial conditions of MIS 22 and 16 appear to have played a major role in the extirpation of a large number of Tertiary species (Tzedakis et al. 2006).

The role of the Iberian Peninsula, however, as an outstanding location for the survival of many tertiary species through the Pleistocene has not been sufficiently emphasised. This role has now been reinforced, supported by the appearance of Aesculus, but also by another series of species characteristic of mesocratic periods, whose presence on the Iberian Peninsula has been clearly established by means of the fossil record. During the Plio-Pleistocene and Lower Pleistocene an important set of tertiary taxa occur on the Peninsula. One of these was Carya, recorded at the Lower Pleistocene sites at Bañolas (Julià and Suc 1980; Leroy 1987), Crespiá (Roiron 1983), Dosquers (de Deckker et al. 1979), Mas Miguel and Mas Grill (Geurts 1977). Less frequent but also present during this period is Pterocarya, which appears at the Tres Pins Plio-Pleistocene (Leroy 1997) site and at the Lower Pleistocene sites at Crespiá (de Villalta and Vicente 1972; Roiron 1983) and Bañolas (Julià and Suc 1980; Leroy 1987). Pollen of this genus has been recorded in pollen-rich marine cores in the NW of Iberia, testifying to its presence until the Middle Pleistocene (MIS 11) (Desprat et al. 2005). Engelhardia, Eucommia and Symplocos make an appearance with two references at the Plio-Pleistocene site at Tres Pins (Leroy 1997) and the Pleistocene site at Bañolas (Leroy 1987). The genus Liquidambar appears at the Plio-Pleistocene site at Tres Pins (Leroy 1997) and at the Lower Pleistocene site at Mas Miguel (Geurts 1977). The genus Parthenocissus has also been recorded for the Quaternary on the Peninsula, occurring during the Lower Pleistocene at the Bañolas site (Julià and Suc 1980; Leroy 1987). Nyssa appears at the Plio-Pleistocene site at Tres Pins (Leroy 1997) and at the Lower Pleistocene sites at Mas Miguel (Geurts 1977). Ostrya appears at the Lower Pleistocene sites at Mas Grill (Geurts 1977) and Dosquers (de Deckker et al. 1979). Lastly, Parrotia appears at the Plio-Pleistocene site at Tres Pins (Leroy 1997) and at the Bañolas (Julià and Suc 1980; 
Leroy 1987) and Crespiá sites (Roiron 1983). It should also be pointed out that in relation to the Iberian Peninsula as a whole, a large group survived until the Middle Pleistocene Transition (MIS 34-20) becoming extinct during this period. This contained Engelhardia, Eucommia, Zelkova, Liquidambar, Myrica, Parthenocissus, Parrotia and Symplocos. To date no references have been found indicating the persistence of these taxa after the Gunz, a period of intense cold that seems to have constituted a serious impediment to many thermophylous and thermohygrophylous species.

Moreover, in the Upper Pleistocene on the Iberian Peninsula a notable group of taxa including Juglans, Carpinus, Platanus, Fagus, Celtis and Castanea can be found. These resisted the harsh climates of the Lower and mid-Pleistocene, persisting throughout the whole fossil record of the Quaternary on the Iberian Peninsula. These taxa maintain a similar general distribution pattern in southern Europe. Thus, references to these species can be found throughout the whole Pleistocene at numerous sites in Europe, whereas in northern Europe, they disappear during the Lower Pleistocene (van der Hammen et al. 1971). One of the most controversial taxa is Juglans. Although Huntley and Birks (1983) reject the Iberian Peninsula as a refuge for this taxon, palaeopollen data at Iberian sites appear to indicate the contrary. Juglans appears in the three main periods of the Pleistocene and constitutes the tertiary taxon with the highest number of fossil references from the Iberian Pleistocene. This taxon therefore undeniably found refuge in the western

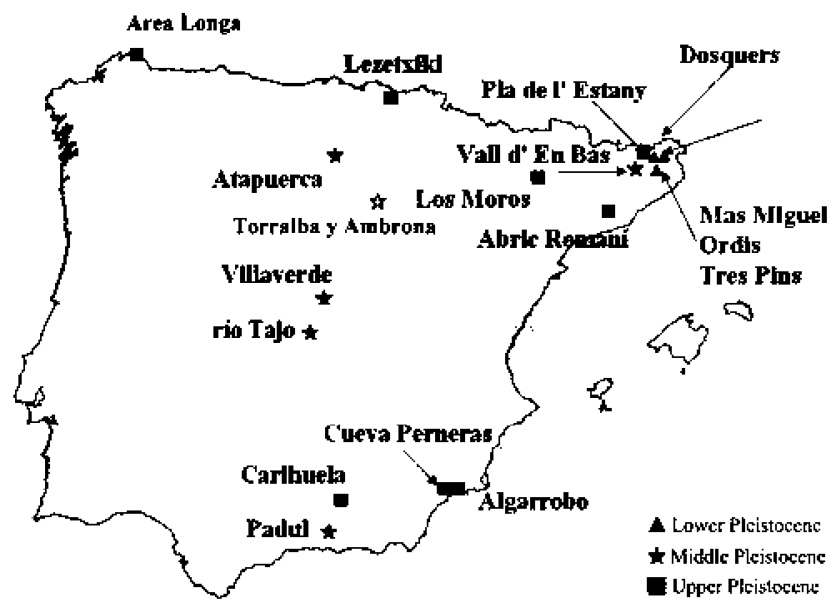

Fig. 7 References to Juglans in the Pleistocene on the Iberian Peninsula (Menéndez Amor and Florschütz 1959; Julià and Suc 1980; Cros et al. 1986; Leroy 1987; Azanza et al. 1988; Galobart et al. 1990; García Antón et al. 1990; Burjachs 1991; García Antón and Sainz Ollero 1991; García Antón 1992; Carrión and Sánchez Gómez 1992; Sánchez Goñi 1992; Burjachs and Julià 1994; Martín et al. 1995; Leroy 1997; Carrión et al. 1998; Carrión et al. 1999; Valle Hernández et al. 2003; Iriarte et al. 2005)

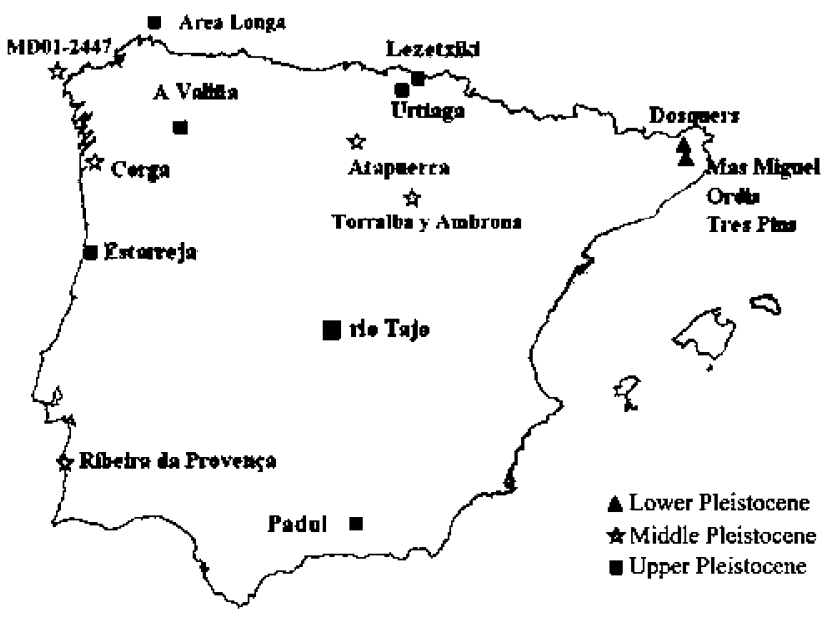

Fig. 8 References to Castanea in the Pleistocene on the Iberian Peninsula (Teixeira and Pais 1976; Geurts 1977, 1979; Julià and Suc 1980; Llana et al. 1991; Sánchez Goñi 1992; Martín et al. 1995; Valle Hernández et al. 2003; Iriarte et al. 2005)

Mediterranean and on the Iberian Peninsula (RenaultMiskovsky et al. 1984; García Antón et al. 1990; Carrión and Sánchez Gómez 1992). As can be seen in Fig. 7, there are numerous references from sites from both inland and coastal and near-coastal areas of the Iberian Peninsula.

Another case to be considered is Castanea, for which there is much fossil evidence on the Peninsula throughout the Pleistocene. As shown in Fig. 8, there is a series of sites well distributed throughout the Peninsula where this taxon can be found. Many of these sites are located close to the coast, although they can also be found in inland areas, such as Atapuerca and the river Tagus. As pointed out by García Antón et al. (1990) the palaeopollen data provide evidence of the autochthonous nature of this taxon. It subsequently persisted on the Peninsula, finding one of its principal refugia areas in the Cantabrian Range, a mountainous region which provided refuge for the main populations of the species during the Holocene (Krebs et al. 2004).

Platanus constitutes the rarest taxon of this group, in that few quaternary references exist for the Peninsula, although in the western European series it was relatively frequent at certain points during the Pleistocene (RenaultMiskovsky et al. 1984). The thermophylous nature of the taxon contrasts with some of these references for the midand Upper Pleistocene inland in the Peninsula, as this region was theoretically exposed to temperature extremes. Platanus appears in the warmer interglacial or interestadial periods of the Quaternary in Europe, and is sensitive to abrupt temperature decreases (Renault-Miskovsky et al. 1984). Its presence at the Atapuerca site, inland in the Peninsula (García Antón and Sainz Ollero 1991), could show how the temperature extremes of the mid-Pleistocene might have been resisted by species for which the fossil 


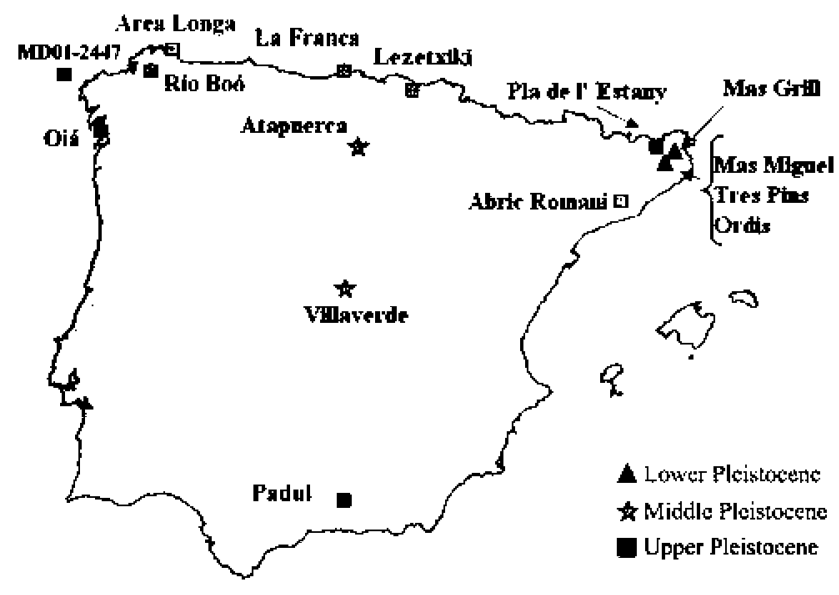

Fig. 9 References to Fagus in the Pleistocene on the Iberian Peninsula. (Menéndez Amor and Florschütz 1959; Geurts 1977, 1979; Julià and Suc 1980; Leroy 1987; Pons and Reille 1988; Burjachs 1991; Sánchez Goñi 1992; Burjachs and Julià 1994; Leroy 1997; Valle Hernández et al. 2003; Iriarte et al. 2005)

record is to say the least scant. Other examples of thermophylous species that seem to have resisted glacial conditions in inland areas are the cork oak (Quercus suber L.) and the hackberry (Celtis), which maintains relict populations in the gorges of Arribes del Duero, in the central-west of the Peninsula (Costa Tenorio et al. 1997).

As regards the beech (Fagus sylvatica L.), although the indigenous origin of this species on the Peninsula is unquestioned, there has on occasions been discussion as to the origin of its populations. Thus, one possibility considered is that following the pre-Holocene extinction of the species on the Iberian Peninsula, this territory might have been re-colonised by populations spreading during the postglacial period from eastern Europe (Balkans) (Huntley and Birks 1983; Demesure et al. 1996), as this was the origin of the population of the taxon on the Peninsula. Hewit (1999) suggests a double origin of the beech populations on the Iberian Peninsula. These were on one hand the tertiary relict populations on the Peninsula and on the other, that from the Balkans in the Holocene re-colonisation. This would confirm the previous theories put forward by other authors (Martínez Atienza and Morla 1992; Costa Tenorio et al. 1997) based on palaeobotanical evidence (Fig. 9). Further studies confirm this idea (Magri et al. 2006). There is also abundant fossil evidence of Carpinus, a taxon that was widely distributed throughout the Peninsula during the Pleistocene, and which suffered a drastic population decrease in the Holocene, possibly related to competition with other species reinforced by climate (Fig. 10). Lastly, the reference to Syringa, a taxon that is currently confined to the Balkans, at Abric Romani (Catalonia, NE of the Peninsula) for the Upper Pleistocene (Burjachs and Julià 1994) is the only one known to date for

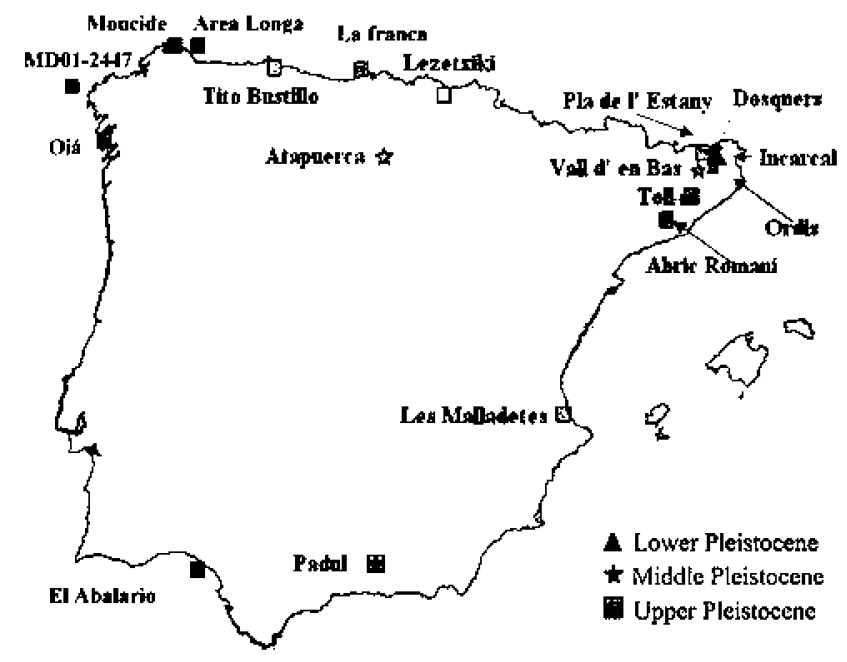

Fig. 10 References to Carpinus in the Pleistocene on the Iberian Peninsula. (Menéndez Amor and Florschütz 1962; Geurts 1977, 1979; Dupré Ollivier 1980; Julià and Suc 1980; Cros et al. 1986; Galobart et al. 1990; Burjachs 1991; Sánchez Goñi 1992; Burjachs and Julià 1994; Zazo et al. 1999; Valle Hernández et al. 2003; Iriarte et al. 2005)

the Iberian Peninsula and the western Mediterranean. However this reference also confirms the relevance of the Peninsula as an area in which tertiary taxa survived over long periods of time throughout the Pleistocene.

Location and features of refuge areas in the Iberian Peninsula

It is difficult to establish the specific locations of "refuge" areas, this problem existing for other areas of Europe (Vogel et al. 1999). The coasts have always been suggested because on the Iberian Peninsula these were not affected by the glaciations (García Antón et al. 1990; Costa Tenorio et al. 1997). Studies of glacial and periglacial evidence for the Peninsula, however, indicate that the effect of the glaciers reached very low elevations, and in some areas, periglacialism practically reached the coastline as, for instance, in Galicia (Pérez Alberti et al. 1998, 1999). This occurred in the NW of the Peninsula where the glacier tongues occasionally descended to an altitude of $700 \mathrm{~m}$, and in the Cantabrian Range, where they descended to $340 \mathrm{~m}$ (Gómez et al. 2000). In both cases, there is periglacial evidence in coastal areas, testifying to the intense cold in this part of the Peninsula at different moments of the Pleistocene. Recent researches on foraminifera assemblages and alkenone analysis from deep sea cores support this idea, pointing out sharp decreases in oceanic temperatures of $10^{\circ} \mathrm{C}$. These can be related to important atmospheric cooling of Iberian coastal areas at several times during the last 425,000 years (Cacho et al. 1999; 
Pailler and Bard 2002; de Abreu et al. 2003; Martrat et al. 2004; Desprat et al. 2006). If refuges existed in coastal areas, they must have been subjected to intense cold at different times.

With regard to the general temperature regime, the north and west of the Peninsula were subjected to lower temperatures than the Mediterranean coast, as a result of their exposure and orientation. Thus, Sánchez Goñi et al. (2002) have pointed out that there was a precipitation gradient between the south Eastern and the south Western parts of the Iberian Peninsula during the last glaciation, during the cold episodes that punctuated this period. Several mesohygrophylous tertiary species persisted on the Cantabria coast during the Pleistocene and the Holocene. A very important factor for these species was undoubtedly the constant humidity in the valleys of northern Spain, along with their relative tolerance to the cold. In support of this idea, refuges have been indicated for taxa such as Fagus (Hewit 1999) and Castanea (García Antón et al. 1990; Krebs et al. 2004). However it should also be pointed out that in areas of the N, NW and W of the Iberian Peninsula, species with very different ecological requirements persisted throughout the Pleistocene, such as certain pteridophytes of palaeotropical affinity (Costa Tenorio et al. 1988, 1990; Morla 2004). These remain as relict species on the Iberian Peninsula: Culcita macrocarpa C. Presl, Davallia canariensis (L.) Sm.,Woodwardia radicans (L.) Sm.,Pteris vitatta L. or Psilotum nudum (L.) PB. It must therefore be assumed that elements related both to mesophylous and thermophylous flora persisted in relatively nearby areas. The factor common to both floristic ensembles was the relatively high degree of humidity in these areas, and we can therefore assume that under conditions of sufficient hydric availability, small variations in topographic and microclimatic situation led to the maintenance or survival of diverse species in the flora. On the east coasts, however, which constitute an area with a higher average temperature, less rainfall and accentuated summertime drought, there was little or no permanence of mesohygrophylous and thermohygrophylous taxa. This appears to highlight the greater importance of the hydric factor in relation to temperature, in the conservation of sensitive pre-Quaternary flora.

On the humid coasts in the north of the Peninsula, the relief is irregular and in the surrounding area there are deep canyons cutting into the carboniferous limestone of the Cantabrian Range. In this abrupt orography of canyons and gorges, the microclimatic effect, with a degree of humidity which is in many cases permanent and with no big temperature variations inland, meso- and thermohygrophylous species might have survived.

It should also be remembered that at times of glacial maximum the coastline would have reached several kilometres further out to sea than at the present. All of these geographic elements would seem to suggest a model presenting a certain degree of diversity among relatively closely situated habitats. This, together with the possibility of small local or regional displacements, accounts for the versatile nature of this part of the Peninsula as refuge areas for both meso- and thermohygrophylous taxa of tertiary origin, during the adverse glacial maxima of the Pleistocene.

According to Bennett et al. (1991), in some places there is no sufficiently wide altitudinal gradient on the Peninsula to allow for the survival of some species. This is not the case for the Cantabrian coast where, a score of miles from the existing coastline, we found elevations of over $2,500 \mathrm{~m}$. This circumstance can be extrapolated to other ranges on the Iberian Peninsula (Costa Tenorio et al. 1997) where mountain ranges such as the Sierra Nevada, the Pyrenees, the Central System or Montseny are sufficiently high to facilitate altitudinal migration of taxa according to climate changes. Thus, for example, in the SE of the Iberian Peninsula, in the karstic Subbetic and Prebetic ranges, periglacial processes have been detected up to altitudes of 600-700 m (Díaz del Olmo 1999) below which limit the more thermophylous species might have found ideal survival conditions. This limit could have fluctuated according to topographic and climatic conditions, providing suitable habitats for the survival of numerous species in gorges and smaller mountain ranges. Mesohygrophylous taxa might have persisted for long periods even inland on the Peninsula in canyons, gorges and small mountain ranges (García Antón et al. 1990; Martín Arroyo 1995), although the intense cold of the plateaux must have led to a high degree of homogenisation of the territory, supporting xerophylous microthermic plants in the colder periods. The continuous humidity in certain areas allowed for the persistence of taxa like Aesculus or Taxodiaceae, the disappearance of which from the Peninsula could be related to increased aridity and summer drought therein. Bearing all this in mind, it should be considered that tertiary taxa recorded in the Pleistocene might have found numerous suitable places for survival on the Iberian Peninsula.

If we are to identify the most favourable characteristics of a geographic space as an optimum "refuge area", we must consider mountains close to the coast, free from aridity or intense hydric deficit, and ecotones, or transition areas between different ecosystems. A good example of this is Mt Montseny, in the Costero-Catalana Mountains, where firs, beech and boreoalpine species co-exist with typical Mediterranean taxa such as the chaste tree (Vitex agnus-castus L.) with species such as the mastic tree (Pistacia lentiscus L.) in close proximity. The habitat diversity in these places, with their permanent water 
courses, has enabled numerous species to persist over very long periods of time, by means of changes in orientation or small rises or drops in altitude. Other territories showing good characteristics as refuge areas can also be indicated: geographic extremes ( $\mathrm{E}$ and $\mathrm{W}$ ) of the Pyrenees, the abovementioned Cantabrian range or many areas in the Betic and Prebetic ranges. To these territories should be added a specific series of mountain ranges, for example the Cazorla or Sierra Morena ranges, the importance of which lies in their location far from glacial influence. These might have played an important role as refuge areas containing relict tertiary species (Costa Tenorio et al. 1990; Carrión et al. 2003).

The study of molecular markers has also contributed to tracing the main refugium areas of the Iberian Peninsula, supporting the ideas expounded in the previous paragraphs. Thus, studies conducted with Pinus pinaster, using cpDNA or allozymes propose a refuge in the $E$ of the Peninsula, the Betic region and Portugal (Vendramin et al. 1998; Salvador et al. 2000). Likewise, cpDNA analyses of Quercus suggest refuge areas for species like $Q$. robur, $Q$. faginea, $Q$. canariensis and $Q$. pyrenaica in the SW, Betic ranges, the Mediterranean coast close to the Ebro basin and the $\mathrm{N}$ of the Peninsula (Olalde et al. 2002; Petit et al. 2002a, b).

\section{Conclusions}

This is the first record of Aesculus aff. hippocastanum as Pleistocene fossil material for the Iberian Peninsula. These findings also represent the first record of fossil wood of Aesculus for Europe.

Study of the palaeodistribution of Aesculus aff. hippocastanum highlights a model of chorological retreat of widely-distributed species in the Miocene and Pliocene. These change from displaying continuous pre-Quaternary areas of distribution to disconnected distributions during the Pleistocene in Mediterranean areas. In Europe, Aesculus aff. hippocastanum formed part of mixed deciduous communities in temperate-warm climates during the Pliocene. Climate changes in the Pleistocene caused the area of these to dwindle, confining relict populations to the southern Mediterranean peninsulas.

Throughout the Pleistocene, the Iberian Peninsula constituted a territory in which tertiary taxa persisted over long periods of time. There is abundant evidence of their presence in the Plio-Pleistocene and Lower Pleistocene. Some disappeared during intermediate phases of the Quaternary whereas others have survived up to the present time. Among the former, with the exception of Aesculus aff. hippocastanum, the pollen record indicates the continued presence of taxa such as Syringa and Platanus, which persisted throughout the Quaternary, only to disappear in very recent times. Other taxa like Castanea, Carpinus, Juglans or Fagus present a fossil record showing their continued presence throughout the Holocene, up to the present.

Accurately locating the refuge areas is a complex task, although we generally considered areas that initially appeared to be quite unaffected by glaciations. However we highlight the fact that, in coastal areas affected by periglaciation, groups of mesohygrophylous or thermohygrophylous taxa have been conserved. Analysis of the data presented here, of other palaeontological and floristic data, and data based on molecular markers, indicates possible refuge areas. These territories are the coastal areas of the Peninsula such as the north (Cantabrian region), northeast (Catalonia and the Levant), west (Portuguese coast), south and southeast (Betic Ranges) of the Iberian Peninsula.

The coastal areas with greater hydric availability (the north and west of the Peninsula) presented favourable environments for the maintenance of meso- and thermohygrophylous taxa, even at times of low temperatures during the Pleistocene. Therein, areas of moderate relief and canyons close to the coast, within a model of short local displacements, allowed for the maintenance of the taxonomic groups in question.

Within a general model of refuges on the scale of the big southern Mediterranean peninsulas, we should highlight the role played by mountain ranges and areas with abrupt orography, mainly situated in the peripheral areas, as these allowed for a certain altitudinal migration of taxa, with subsequent rapid re-colonisation. If these mountains are within ecotone zones, their potential as refuge areas increases. Examples of this on the Iberian Peninsula are the Costero-Catalana Mountains, extremes of the Pyrenees and the Cantabrian Range.

Acknowledgments We wish to dedicate this paper to our friend and colleague Javier Maldonado, a palaeobotanist on our team who passed away in August 2004. We also wish to thank Rafael Mora, Salvador Moyà and the Catalonia Regional Government.

\section{References}

Abreu L de, Shackleton NJ, Schönfeld J, Hall M, Chapman M (2003) Millennial-scale climate variability off the western Iberian margin during the last two glacial periods. Mar Geol 196:1-20

Azanza B, Baldellou V, Cuchi JA, López P, Montes L, Utrilla P (1988) Cronoestratigrafía de la cueva Musteriense de los Moros (Gabasa, Huesca). Cuaternario y Geomorfología 2:1-12

Bennett KD, Tzedakis PC, Willis KJ (1991) Quaternary refugia of north European trees. J Biogeogr 18:103-115

Berástegui X, Casanovas J, Moyà $\mathrm{S}(2000) \mathrm{El}$ jaciment paleontològic de Cal Guardiola. Una finestra oberta al plistocè inferior de Catalunya. Contextualització geològica. Tribuna d'Arqueologia 1997-1998:255-277 
Bertolani D, Accorsi CA, Pelosio G, Raffi S (1979) Palynology and stratigraphy of the Pliopleistocene sequence of the Stirone river (Northern Italy). Pollen Spores 21:149-167

Bertoldi R, Río D, Thunell R (1989) Pliocene-Pleistocene vegetational and climatic evolution of the south central Mediterranean. Palaeogeogr Palaeoclim Palaeoecol 72:263-275

Brun A (1976) La végétation au Pléistocene inferieur dans le Massif Central. Les civilitations neolithiques et protohistoriques 1, C.N.R.S., pp 476-479

Burgh J van der (1978) The Pliocene flora of Fortuna-Garsdorf I. Fruits and seeds of angiosperms. Rev Palaeobot Palynol 26:173211

Burgh J van der, Zetter R (1998) Plant mega- and microfossil assemblages from the Brunssumian of "Hambach" near Düren, BRD. Rev Palaeobot Palynol 101:209-256

Burjachs F (1991) Evolució de la vegetació i paleoclimatología desde fa mes de 85.000 anys a la regió de Olot. Análisi polinica del Pla de l' Estany (Sant Joan les Fonts, La Garrotxa). Vitrina 5:39-46

Burjachs F (2000) Informe palinològic del jaciment de Cal Guardiola (Terrassa, Vallès Occidental). Servei d'Arqueología de la Generalitat de Catalunya. Barcelona (unpublished report)

Burjachs F, Julià R (1994) Abrupt climatic changes during the last glaciation based on pollen analysis of the Abric Romaní, Catalonia, Spain. Q Res 42:308-315

Cacho I, Grimalt JO, Pelejero C, Canals M, Sierro FJ, Flores JA, Shackleton NJ (1999) Dansgaard-Oeschger and Heinrich event imprints in Alboran Sea paleotemperatures. Paleoceanography 14:698-705

Carrión JS, Sánchez-Gómez P (1992) Palynological data in support of the survival of Walnut (Juglans regia L.) in the western Mediterranean area during last glacial times. J Biogeogr 19:623630

Carrión JS, Munuera M, Navarro C (1998) The palaeoenviroment of Carihuela Cave (Granada, Spain): a reconstruction on the basis of palinological investigations of cave sediments. Rev Palaeobot Palynol 99:317-340

Carrión JS, Munuera M, Navarro C, Burjachs F, Dupré M, Walker MJ (1999) The palaeoecological potential of pollen records in caves: the case of Mediterranean Spain. Q Sci Rev 18:1061-1073

Carrión JS, Yll EI, Legaz AJ, Chaín C, López A (2003) Glacial refugia of temperate, Mediterranean and Ibero-North African flora in south-eastern Spain: new evidence from cave pollen at two Neanderthal sites. Glob Ecol Biogeogr 12(2):119-129

Carrol E, Wood JR (1972) Morphology and phytogeography: the classical approach to the study of disjuntions. Ann Missouri Bot Gard 59:107-124

Chochieva KI (1965) Flora i rastitel 'nost' Chaudiuskogo gorizonta Gurig-Trudi. Inst Paleobiol Akad Nauk Gruz SSr 52:219-222

Costa Tenorio M, Morla C, Sainz Ollero H (1988) Consideraciones acerca de la evolución del paisaje vegetal de la península Ibérica durante el Cuaternario reciente, Actes del Simposi Internacional de Botánica Pius Font i Quer. Fanerogamia 2:427-238

Costa Tenorio M, Morla C, Sainz Ollero H (1990) La evolución de los bosques de la península Ibérica: una interpretación basada en datos paleobiogeográficos. Ecología FS 1:31-58

Costa Tenorio M, Morla C, Sainz Ollero H (eds) (1997) Los bosques ibéricos: una interpretación geobotánica. Planeta, Barcelona

Cros J, Pérez Obiol R, Roure J (1986) Primeres dades sobre la vegetació i el clima del Quaternari Mitjà a Olot (NE Península Ibérica). Collect Bot 16:365-369

Deckker P de, Geurts MA, Julià R (1979) Seasonal rhythmites from a lower pleistocene lake in northeastern Spain. Palaeogeogr Palaeoclim Palaeoecol 26:43-71

Demesure B, Comps B, Petit RJ (1996) Chloroplast DNA phylogeography of the common beech (Fagus sylvatica L.) in Europe. Evolution 50:2515-2520
Desprat S, Sánchez Goñi MF, Turon JL, McManus JF, Loutre MF, Duprat J, Malaizé B, Peyron O, Peypouquet JP (2005) Is vegetation responsible for glacial inception during periods of muted insolation changes? Q Sci Rev 24:1361-1374

Desprat S, Sánchez Goñi MF, Turon JL, Duprat J, Malaizé B (2006) Climatic variability of Marine Isotopic Stage 7: direct land-seaice correlation from a multiproxy analysis of a northwestern Iberian margin deep-sea core. Q Sci Rev 25:1010-1026

Díaz del Olmo F (1999) Depósitos periglaciares y carbonatos en las Cordilleras Béticas no glaciadas: morfogénesis y paleoambientes. Procesos y formas periglaciares en la montaña mediterránea. IV Reunión IPA-España (Resúmenes). Instituto de Estudios Turolenses, Teruel

Dupré Ollivier M (1980) Análisis polínico de sedimentos arqueológicos de la cueva de les Malladetes (Barx, Valencia). Cuad Geogr 26:1-22

Engelhardt $H$ (1885) Die tertiaerflora des Jesnitengrabens bei Kundratitz in Nordboehmen. Ein Neuer Beitrag zur kenntniss der fossilen pflanzen boehmens. Nova Acta Leopold 48/3:1-112

Ferguson DK, Knobloch E (1998) A fresh look at the rich assemblage from the Pliocene sink-hole of Willershausen, Germany. Rev Palaeobot Palynol 101:271-286

Galobart A, Maroto J, Menéndez E, Ros X, Gaete R, Colomer F (1990) El Yacimiento del Pleistoceno Inferior de Incarcal (Crespià, Girona). Comunicación de la II reunión de la tafonomía y fosilización, pp 161-167

García Antón M (1992) Paleovegetación del Pleistoceno Medio de Atapuerca a través del análisis polínico. Actas, Evolución Humana en Europa y los yacimientos de la Sierra de Atapuerca 1:147-165

García Esteban L, Guindeo A (1990) Anatomía de las maderas de frondosas españolas, A.I.T.I.M. Coimpress, Madrid

García Antón M, Sainz Ollero H (1991) Pollen records from the middle Pleistocene Atapuerca site (Burgos, Spain). Palaeogeogr Palaeoclim Palaeoecol 85:199-206

García Antón M, Morla C, Sainz Ollero H (1990) Consideraciones sobre la presencia de algunos vegetales relictos terciarios durante el Cuaternario en la Península Ibérica. Bol Real Soc Esp Hist Nat (Secc Biol) 86:95-105

Geurts MA (1977) Approche palynostratigraphique des depots calcareux quaternaires en Catalogne. Acta Geológica Hispánica 12(4-6):86-89

Geurts MA (1979) Approche palynostratigraphique des depots calcareux quaternaires dans la region de Banyoles-Besalc (Catalogne). Actas de la IV Reunión del grupo de trabajo del Cuaternario, pp 106-115

Givulescu R (1990) Flora Fosila a Miocenului superior de la Chiuzbaia (Judetul Marambures), Ed. Academiei Române, Bucarest

Gómez A, Martí C, Franch F (2000) Evolución reciente de los estudios de geomorfología glaciar y periglaciar en España (1980-2000): Balance y perspectivas. Scripta Nova. Revista electrónica de Geografía y Ciencias Sociales, Universidad de Barcelona $\mathrm{n}^{\circ} 77$

Gregor HJ (1990) Contributions to the Late Neogene and Early quaternary floral history of the Mediterranean. Rev Palaeobot Palynol 62:309-338

Greguss P (1947) The identification of central-european dicotyledoneus trees and shrubs based on xylotomy. Hungarian Museum of Natural History, Budapest

Gutiérrez Elorza M (ed) (1994) Geomorfología de España. Rueda, Madrid

Hammen T van der, Wijmstra TA, Zagwijn WH (1971) The floral record of the late cenozoic of Europe. In: Turekian KK (ed) The Late Cenozoic glacial ages. Yale University Press, New Haven, pp $392-424$ 
Hardin JW (1957a) A revision of the American Hippocastanaceae I. Brittonia 9:145-171

Hardin JW (1957b) A revision of the American Hippocastanaceae II. Brittonia 9:173-195

Hardin JW (1960) Studies in the Hippocastanaceae, V. Especies of the old World. Brittonia 12:26-38

Hewitt GM (1999) Post-glacial re-colonization of European biota. Biol J Linnean Soc 68:87-112

Huntley B, Birks HJ (1983) An atlas of past and present pollen maps for Europe: 0-13.000 years ago. Cambridge University Press, Cambridge

Ilinskaja IA (1968) Flora neógena de la región precarpática de Ucrania. Neogene Flora from precarpatica Región of Ucrania. Nauka, Leningrado

Iriarte MJ, Gómez-Orellana L, Muñoz Sobrino C, Ramil Rego P, Arrizabalaga A (2005) La dinámica de la vegetación en el NW peninsular durante la transición del paleolítico medio al paleolítico superior. Museo de Altamira. Monografías 20:231253

Jacquiot C, Trenard Y, Dirol D (1973) Atlas d'anatomie des bois des angiospermes (essences feuilles). Centre technique du bois, Paris, 2 vols

Jan du Chene R (1976) La végétation au Pleistocène inférieur en Bourgogne. La Préhistoire française, tome 1, pp 481-482

Julià R, Suc JP (1980) Analyse pollinique des dépots lacustres du Pléistocène Inférieur de Banyoles (Bañolas, site de la Bòbila Ordis-Espagne: un élément nouveau dans la reconstitution de ĺhistoire paléoclimatique des régions méditerranéennes dEurope occidentale). Geobios 13:5-19

Krebs P, Conedera M, Pradella M, Torriani D, Felber M, Tinner W (2004) Quaternary refugia of the sweet chesnut (Castanea sativa Mill.): an extended palynological approach. Veget Hist Archaeobot $13: 145-160$

Leroy S (1987) Analyse palynologique de deux nouvelles sections du Pleistocene Inferieur de Banyoles (Catalogne). In: Civis Llovera J, Valle Hernández MF (eds) Actas del VI Simposio de Palinología. A.P.L.E., Salamanca, pp 307-313

Leroy S (1997) Climatic and non-climatic lake-level changes inferred from a Plio-Pleistocene lacustrine complex of Catalonia (Spain): palynology of the Tres Pins sequences. J Paleolimnol 17:347367

Llana JC, Soto MJ, Fernández C, Martínez A, Pumarejog P, Villar R (1991) Cova da Valiña (Castroverde, Lugo) un yacimiento del Paleolítico Superior Inicial en Galicia (Campañas de 1987 y 1988). Arqueoloxía/Investigación 5. Xunta de Galicia. Santiago

Lona F, Bertoldi R (1972) La storia del Plio-Pleistocene italiano in alcune sequenze vegetazionali lacustri e marine. Mem Accad Naz Lincei 11:1-47

Mädler K (1939) Die pliozäne Flora von Frankfurt am Main. Abh Senckenb Naturforsch Ges 446:1-202

Magri D, Vendramin G, Comps B, Dupanloup I, Geburek Th, Gömöry D, Latalowa M, Litt Th, Paule L, Roure JM, Tantau I, Knaap WO van der, Petit RJ, Beaulieu JL de (2006) A new scenario for the Quaternary history of European beech populations: palaeobotanical evidence and genetic consequences. New Phytol 171:199-221

Mai DH (1965) Eine pliozäne Flora von Kranichfeld in Thüringen. Mitteilungen 1:37-64

Maley J (1980) Les changements climatiques de la fin du Tertiaire en Afrique: leur conséquence sur l' apparition du Sahara et de sa végétation. In: Williams MAJ, Hugues F (eds) The Sahara and the Nile: quaternary environments and prehistoric occupation in northern Africa. Balkema, Rotterdam, pp 63-86

Mariotti Lippi M (1989) Ricerche palinologiche sul Messiniano di Eraclea Minoa (AG) nel quadro paleofloristico e paleovegetazional del tardo Miocene italiano. Webbia 43:169-199
Martín Arroyo T, Ruiz B, Pérez-González A (1995) Reconstrucción paleoclimática y paleoambiental durante el Pleistoceno Medio en el valle del río Tajo: primeros datos polínicos. Actas IX Reunión Nac. sobre el Cuaternario, pp 347-361

Martínez Atienza F, Morla C (1992) Aproximación a la paleocorología holocena de Fagus en la península Ibérica a través de datos paleopolínicos. Investigaciones Agrarias (Fuera de Serie) 1:135-145

Martrat B, Grimalt J, Lopez-Martinez C, Cacho I, Sierro FJ, Flores JA, Zahn R, Canals M, Curtis JH, Hodell DA (2004) Abrupt temperature changes in the western Mediterranean over the past 250,000 years. Science $306: 1762-1765$

Menéndez Amor J, Florschütz F (1959) Algunas noticias sobre el ambiente en el que vivió el hombre durante el gran interglaciar en dos zonas de ambas Castillas. Estudios Geológicos 15:277283

Menéndez Amor J, Florschütz F (1962) Resultados del análisis polínico de sedimentos tardiglaciares en la cueva del Toll (Moyá, Barcelona). Estudios Geológicos 18:93-95

Morla C (2004) El paisaje vegetal ibérico durante el Cuaternario. Monograf Jard Bot Córdoba 11:75-93

Olalde M, Herrán A, Espinel S, Goicoechea PG (2002) White oaks phylogeography in the Iberian Peninsula. For Ecol Manage 156:89-102

Pailler D, Bard E (2002) High frequency palaeoceanographic changes during the past $140,000 \mathrm{yr}$ recorded by the organic matter in sediments of the Iberian margin. Palaeogeogr Palaeoclim Palaeoecol 181:431-452

Palacios P de (1997) Anatomía de géneros y especies de coníferas del hemisferio norte. Universidad Politécnica de Madrid, E.T.S.I. Montes. Doctoral Thesis. Madrid

Pérez Alberti A, Costa Casais C, Blanco Chao R (1998) ĹImportance des processus dorige froide sur la cote atlantique de la Galice (Nord-Ouest de la Peninsule Ibérique). Environ Periglaciaires 5:21-32

Pérez Alberti A, Costa Casais C, Martínez Cortizas A (1999) Nuevas apoprtaciones al conocimiento del Cuaternario reciente en la costa atlántica de Galicia. In Geoarqueología i Quaternari litoral Memorial Pilar Fumanal. Valencia. Dpto. Geografía, Universitat de Valencia, pp 381-390

Petit RJ, Csaikl UM, Bordács S, Burg K, Coart E, Cottrell J, Dam BC van, Deans JD, Dumolin-Lapègue S, Fineschi S, Finkelday R, Gillies A, Glaz I, Goicoechea PG, Jensen JS, König A. Lowe AJ, Madsen SF, Mátyás G, Munro RC, Pemonge MH, Popescu F, Slade D, Olalde M, Tabbener H, Taurchini D, Vries SMG de, Ziegenhagen B, Kremer A (2002a) Chloroplast DNA variation in European white oaks: phylogeography and patterns of diversity based on data from 2600 populations. For Ecol Manage 156:526

Petit RJ, Brewer S, Bordács S, Burg K, Cheddadi R, Coart E, Cottrell J, Csaikl UM, Dam BC van, Deans JD, Espinel S, Fineschi S, Finkeldey R, Glaz I, Goicoechea PG, Jensen JS, König A, Lowe AJ, Madsen SF, Mátyás G, Munro RC, Popescu F, Slade D, Tabbener H, Vries SMG de, Ziegenhagen B, Beaulieu JL de, Kremer A (2002b) Identification of refugia and post-glacial colonisation routes of European white oaks based on chloroplast DNA and fossil evidence. For Ecol Manage 156:49-74

Petit RJ, Aguinagalde I, Beaulieu JL de, Bittkau Ch, Brewer S, Cheddadi R, Ennos R, Fineschi S, Grivet D, Lascoux M, Mohanty A, Müller-Starck G, Demesure-Musch B, Palmé A, Martín JP, Rendell S, Vendramin G (2003) Glacial refugia: hotspots but not melting pots of genetic diversity. Science 300:1563-1565

Polunin O, Walters M (1989) Guía de la vegetación de Europa. Omega, Barcelona 
Pons A, Reille M (1988) The Holocene and upper Pleistocene pollen record from Padul (Granada, Spain): a new study. Palaeogeogr Palaeoclim Palaeoecol 66:243-263

Postigo Mijarra JM (2003) Contribución al conocimiento de la vegetación pleistocena de la península lbérica. Estudio paleobotánico de macrorrestos vegetales fósiles. Universidad Autónoma de Madrid, Doctoral Thesis, Madrid

Quézel P (1985) Definition of the Mediterranean region and the origin of its flora. In: Gómez-Campo C (ed) Plant conservation in the Mediterranean area. Dr. Junk. Publishers, Dordrecht, pp 9-24

Ravazzi C, Rossignol M (1995) Vegetation change in a climatic cycle of Early Pleistocene age in the Leffe Basin (northern Italy). Palaeogeogr Palaeoclim Palaeoecol 117:105-122

Raven PH, Axelrod DI (1974) Angiosperm biogeography and past continental movements. Ann Mo Bot Gard 61:539-673

Raven PH, Axelrod DI (1978) Origin and relationships of the California flora. Univ Calif Publ Bot 72:1-34

Reid C, Reid EM (1915) The pliocene floras of the Dutch-prussian Border. Meded. Rijksopsporing Delfstoffen 6:1-178

Renault-Miskovsky J, Girard M (1978) Analyse pollinique du remplissage Pléistocène du Vallonnet (Roquebrune-Cap-Martin, Alpes-Maritimes). Géologie Méditerranéenne 5(4):385-402

Renault-Miskovsky J, Bui-Thi-Mai M, Girard M (1984) A propos de l' indigenat ou de l'introduction de Juglans et Platanus dans l'ouest de l'Europe au Quaternaire. Rev Paléobiol Special volume: $155-178$

Roiron P (1983) Nouvelle étude de la macroflore plio-pleistocène de Crespià (Catalogne, Espagne). Geobios 16:687-715

Salvador L, Alia R, Gil L (2000) Genetic variation and migration pathways of maritime pine (Pinus pinaster Ait.) in the Iberian Peninsula. Theor Appl Genet 100:89-95

Sánchez Goñi MF (1992) Analyse palynologique de sites prehistoriques du Pays basque: premiers resultats pour les grottes de Lezetxiki et Urtiaga. The late Quaternary in the western Pyreneen region. Ed. Univ. Pais Vasco, pp 207-233

Sánchez Goñi MF, Cacho I, Turon JL, Guiot J, Sierro FJ, Peypouquet JP, Grimalt JO, Shackleton NJ (2002) Synchroneity between marine and terrestrial responses to millennial scale climatic variability during the last glacial period in the Mediterranean region. Clim Dyn 19:95-105

Schopf JM (1975) Modes of fossil preservation. Rev Palaeobot Palynol 20:27-53

Schweingruber FH (1978) Mikroskopische Holzanatomie. Zürcher A.G., Zug

Schweingruber FH (1990) Anatomie europäischer Hölzer. Paul Haupt, Bern und Stuttgart

Sordelli F (1896) Flora fossilis insubrica. Studi sulla vegetazione in Lomlhardia durante i tempi geologici. Milano

Spicer RA (1991) Plant taphonomic processes. In: Allison PA, Briggs DEG (eds) Taphonomy releasing. The data locked in the fossil record. Plenum, New York, pp 71-113

Suc JP (1976) La végétation au Pléistocene inferior en Languedoc mediterranéen Roussillon et Catalogne. C.N.R.S., pp 472-475

Svenning JC (2003) Deterministic Plio-Pleistocene extinctions in the European cool-temperate tree flora. Ecol Lett 6(7):646-653
Szafer W (1954) Pliocénska flora okolo Czorstyna. The Pliocene flora from the vicinity of czorsztyn (west carpatians) and its relationship to the Pleistocene. Inst Geol Prace 11:1-238

Szafer W (1961) Miocene flora from Stare Gliwice in upper Silesia. Inst Geol Prace 33:1-205

Teixeira C, Pais J (1976) Introduçao a paleobotânica as grandes fases de evolucao dos vegetais. Flora cenozoica portuguesa, origem da flora actual. INIC, Lisboa, pp 209

Tzedakis PC, Hooghiemstra H, Pälike H (2006) The last 1.35 million years at Tenaghi Philippon: revised chronostratigraphy and longterm vegetation trends. Q Sci Rev 25:3416-3430

Urban B, Arias C, Bigazzi G, Bonadona FP (1983) Early Pleistocene Palynostratigraphy of fornace tini, valle Ricca (central Italy) Palaeogeogr Palaeoclim Palaeoecol 41:153-164

Valle MF (1983) Estudio palinológico del NE de España. Universidad de Salamanca

Valle MF, Civis J (1978) Investigaciones palinológicas en el Plioceno Inferior de Can Albareda (Barcelona). Palinología, Special volume 1:463-468

Valle Hernández M, Rivas-Carballo MR, Lucini M, Ortiz JE, Torres $\mathrm{T}$ (2003) Interpretación paleoecológica y paleoclimática del tramo superior de la turbera de Padul (Granada, España). Pollen 13:85-95

Velitzelos E, Gregor HJ (1990) Some aspects of the neogene Floral History in Greece. Rev Palaeobot Palynol 62:291-307

Vendramin GG, Andizei M, Madaghiele A, Bucci G (1998) Distribution of genetic diversity in Pinus pinaster Ait. as revealed by chloroplast microsatellites. Theor Appl Genet 97:456-463

Villalta JF de, Vicente J (1972) Una flora del Cuaternario antiguo en las cercanías de Crespià. Acta Geol Hispanica 7:120-128

Vogel JC, Rumsey FJ, Jakob J, Barrett JA, Gibby M (1999) Where are the refugia in Europe? Evidence from pteridophytes. Biol J Linnean Soc 66:23-37

Worobiec G (2003) New fossil floras from Neogene deposits in the Belchatow Lignite mine. Acta Palaeobotanica, suppl 3. pp 3-133

Xiang QY, Crawford DJ, Wolfe AD, Tang YCh, DePampilis CLW (1998) Origin and biogeography of Aesculus L. (Hippocastanaceae): a molecular phylogenetic perspective. Evolution 52:988997

Zagwijn WH (1960) Aspects of the Pliocene and Early Pleistocene vegetation in the Netherlands. Mededel Geol Sticht., Ser. C, $3,1,5,1$

Zagwijn WH (1967) Ecologic interpretation of a pollen diagram from Neogene beds in the Netherlands. Rev Palaeobot Palynol 2:173181

Zazo C, Dabrio CJ, Borja F, Goy JL, Lezine AM, Lario J, Polo MD, Hoyos M, Boersma JR (1999) Pleistocene and Holocene aeolian facies along the Huelva coast (southern Spain): climatic and neotectonic implications. Geologie en Mijnbouw 77:209-224

Zhilin SG (1974) The Tertiary floras of the Plateau Ustjurt (Transcaspia). Komarov Botanical Institute of the Academy of Sciences of the USSR, Leningrad

Zittel KA (1891) Traité de Palèontologie. Partie II, Paléophytologie. Octave Doin Éditeurs. Paris 